Riga, Latvia, March 12-13, 2021

\title{
YOUTH OF UKRAINE: CHALLENGES OF A NEW MILLENIUM
}

\author{
Vitalii Kotsur ${ }^{1}$ \\ Lesya Kotsur ${ }^{2}$
}

DOI: https://doi.org/10.30525/978-9934-26-050-6-31

Modern young generation plays important role in functioning of Ukraine. Number of regulatory documents, designed to ensure the social, material, spiritual, cultural and political condition of young people regulate youth policy of the state [9].

Young people in Ukraine are persons in age from 15 to 34 years. For today, there are about 12.7 million of them in the country. However, during the last decades total population of Ukraine is decreasing, and so do the number of young people. For example, during the period from year 2000 to 2014, number of young people fell by 1.5 million. In general, share of young townspeople in Ukraine is $70 \%$. In the countryside it is close to $27 \%$. The largest reduction of young population in Ukraine took place in the eastern industrial regions of our country - Donetsk, Dnipropetrovsk, Luhansk regions during the last 14 years. In Kyiv, on the contrary, number of young people has increased $[4 ; 10]$.

«The youngest» is the population in Volyn, Zakarpatskyi, IvanoFrankivsk, Rivne, Chernivtsi regions. Kyiv, as well as Kharkiv and Odessa regions are most attractive in terms of life prospects and opportunities of job placement for young people [10]. At the same time best financing of the needs of youth is, excepting the capital, in Sumy region [3].

Major priorities in a life of young Ukrainians are: birth and education of children $-48 \%$; search of a job and achieving some results in it $-44 \%$; earning / getting enough money 36\%; search for their love and / or marriage $21 \%$; health (healthy lifestyle, overcoming some illness, etc.) - 19\%; freedom and independence in their decisions and actions 18\%; education (including self-education) $-15 \%$ and interesting leisure - 15\% [6].

It is natural that priorities change while person becomes older. Young people in age of 14-19 describe their main priorities as education and work; at the age of 20-24 - as work; for people 24-34 years old main priorities are related to birth and education of their children. With age, desire in searching love or marriage reduces (often because young people achieve this goal while getting older) and the priority of goals, related to children, earning money and health increases.

\footnotetext{
${ }^{1}$ Hryhorii Skovoroda University in Pereiaslav, Ukraine

${ }^{2}$ Hryhorii Skovoroda University in Pereiaslav, Ukraine
} 
Evaluating their financial needs, only 1\% of young people in Ukraine believe that they have already reached desired financial situation. Also, problem of providing youth with apartments is quite acute - in the age group of 30-34, only half of respondents have their own home, 33\% live with their parents or relatives, rest of them rent an apartment / room or live in a hostel [6, p. 5].

Only $67 \%$ of Ukrainian youth are satisfied (mostly or almost) with such an important thing as education, while $14 \%$ are completely dissatisfied (others have chosen a neutral position or failed to answer). Unemployment among Ukrainian youth reaches $9 \%$.

Priority kinds of leisure for Ukrainian youth are: for $62 \%$ - it is traveling abroad; for $50 \%$ - traveling across Ukraine; for 35\% - concerts or shows; for $30 \%$ - sport (p. 5-6). Also, most of young people are satisfied with the services of medical institutions, while private medical institutions satisfy them more than services of state / communal institutions. One of the dissatisfaction factors is bribery [6, p. 7].

More than $5 \%$ of people living in Ukraine are vegetarians, which mean almost 2 million people. Most of those who refuse to eat meat, fish and seafood are young people. According to research, the most common age of Ukrainian vegetarians is from 18 to 20 years. Most of vegans - or those who refuse to eat all the products of animal origin, in particular non-vegetable milk and cheese, have the same age [1].

In the environment of youth there is an effective and targeted public selforganization in informal associations and movements [11; 12; 13]. Best confirmation of this trend were the protests at the end of 2013 - early 2014 . Youth and students were one of the most active and successive forces of the Revolution of Dignity. Thanks to their uncompromising struggle we were able to defend the irreversibility of democratic transformations in Ukraine and its choice of integration to Europe [10].

Negative phenomenon among Ukrainian youth is suicide, mostly among the age from 15 to 19 . Unfortunately, alcohol, drugs and smoking are also widespread among the youth in Ukraine. According to the data of expert R. Safiullina, in 2010, 45\% of boys and 35\% of girls in Ukraine smoke cigarettes [2]. However, number of smokers among young people in Ukraine decreased by $27 \%$ in 2017 [5].

$68 \%$ of boys and $64 \%$ of girls drink alcohol. Besides, about $80 \%$ of drug addicts are young people from 14 to 35 years old. For example, over the past 10 years (from 2000 to 2010), part of drug addicted among minors has increased by 6-8 times [2].

To prevent negative manifestations among the youth in Ukraine, over 15 national and interagency programs aimed at integration of a healthy lifestyle are realized [2; 14]. «Concept of the State Target Social Program» 
Youth of Ukraine «for 2016-2020» is playing an important role among them. These program is based on a scientific analysis of the state and problems of development of Ukrainian youth, results of the previous stage of realization of the state policy in the youth field in Ukraine, and also takes into account program requirements and perspectives defined by the Strategy of the Development of State Youth Policy during the period up to 2020, which is governing by the European principles of youth development policy [7].

Main problems that need to be solved in these concept are:

- unsystematic nature of formation of a civic position and nationalpatriotic consciousness among young people;

- lack of motivation and skills needed for independent acquisition of knowledge among the youth ;

- low level of employment among young people in the labor market for the chosen profession and lack of practical skills and abilities of young specialists;

- complexity and long terms of youth transition from education to stable and satisfactory work;

- low temps of entrepreneurship development among youth;

- insufficient use of innovative potential of youth;

- low quality of secondary education of youth;

- high morbidity and mortality rates among young people, poor motivation for living healthy and safe lifestyle, lack of knowledge and skills in the field of life safety;

- lack of knowledge, skills and abilities outside of the educational system in order to increase the competitiveness of youth in the labor market;

- low level of professional orientation;

- lack of steady tendency in reducing of the level of crime in the youth environment and violence, no systematic work in the field of their prevention;

- low level of providing young families with apartments;

- low level of organization and culture of youth leisure;

- weak integration of Ukrainian youth into European and world youth community [7; 8].

So, for today situation in the youth environment is complicated. That's why, in Ukraine, there is a need in providing more pragmatic and wellfounded policy in the youth field, which means training young people as socially active citizens able to live in a self-organized community and society.

\section{References:}

1. V Ukraini dedali bilshe molodi vidmovliaietsia vid vzhyvannia miasa. URL: https://tsn.ua/ukrayina/v-ukrayini-dedali-bilshe-molodi-vidmovlyayetsya-vidvzhivannya-m-yasa-1021490.html 
2. V Ukraini zrostaie kilkist samohubstv sered molodi. URL: https://health.unian.ua/country/421134-v-ukrajini-zrostae-kilkist-samogubstvsered-molodi.html

3. De $\mathrm{v}$ Ukraini naibilshe dbaiut pro molod? Porivnialnyi analiz. URL: $\quad$ http://www.mnr.in.ua/analtika/de-v-ukran-nayblyshe-dbayuty-pro-molodyporvnyalyniy-analz.html

4. Demohrafichna ta sotsialna statystyka / Naselennia ta mihratsiia. URL: http://www.ukrstat.gov.ua/operativ/menu/menu_u/ds.htm

5. Kilkist kurtsiv sered molodi $v$ Ukraini zmenshylasia na $27 \%$. URL: http://studway.com.ua/kilkist-kurciv/

6. «Molod Ukrainy-2015» molodi. URL: https://www.gfk.com/fileadmin/user_ upload/dyna_content/UA/Molod_Ukraine_2015_UA.pdf

7. Pro skhvalennia Kontseptsii Derzhavnoi tsilovoi sotsialnoi prohramy «Molod Ukrainy» na 2016-2020 roky / Rozporiadzhennia Kabinetu Ministriv Ukrainy, vid 30 veresnia 2015 r. № 1018-r. URL: https://www.kmu.gov.ua/ua/npas/248528402?=print

8. Smuk O., Kozubovskyi M. Sotsialni problemy suchasnoi molodi Ukrainy v umovakh transformatsii politychnoi ta sotsialno-ekonomichnoi system. Naukovyi Visnyk Uzhhorodskoho natsionalnoho universytetu. Seriia «Pedahohika, sotsialna robota», vol. 30, pp. 159-161.

9. Sotsialni problemy molodi v Ukraini / za rezultatamy doslidzhennia hromadskoi dumky Tsentru Razumkova (2003-2006 rr.). URL: http://old.niss.gov.ua/monitor/ april08/27.htm

10. Ukraina vidznachaie Den molodi / Ukrinform - Multymediina platforma inomovlennia Ukrainy, 25.06.2017. URL: https://www.ukrinform.ua/rubricsociety/2253792-ukraina-vidznacae-den-molodi.html

11. Kotsur V., Haidaienko I. (2014) Molodizhnyi rukh v Ukraini (druha polovyna 80-kh rr. XX st.) / Pereiaslavskyi litopys: zb. nauk. Statei, vol. 6 / [red. kolehiia: Kotsur V.P. (holov. red.) ta in.]. Pereiaslav-Khmelnytskyi, pp. 99-107.

12. Kotsur V., Haidaienko I. (2014) Molodizhnyi rukh v universytetakh Kyieva naprykintsi 80-kh rr. XX st. / Pereiaslavskyi litopys: zb. nauk. Statei, vol. 6 / [red. kolehiia: Kotsur V.P. (holov. red.) ta in.]. Pereiaslav-Khmelnytskyi, pp. 107-114.

13. Haidaienko I., Kotsur V. (2014) Molodizhnyi rukh i molodizhni orhanizatsii v Ukraini u 90-ti roky XX st. Humanitarnyi Visnyk DVNZ «Pereiaslav-Khmelnytskyi derzhavnyi pedahohichnyi universytet imeni Hryhoriia Skovorody», vol. 32, pp. 247-260.

14. Kotsur V. (2014) Derzhavna molodizhna polityka v Ukraini ta mekhanizmy yii realizatsii na pochatku 90-kh rokiv XX st. Humanitarnyi Visnyk DVNZ «PereiaslavKhmelnytskyi derzhavnyi pedahohichnyi universytet imeni Hryhoriia Skovorody», vol. 33, pp. 240-251. 